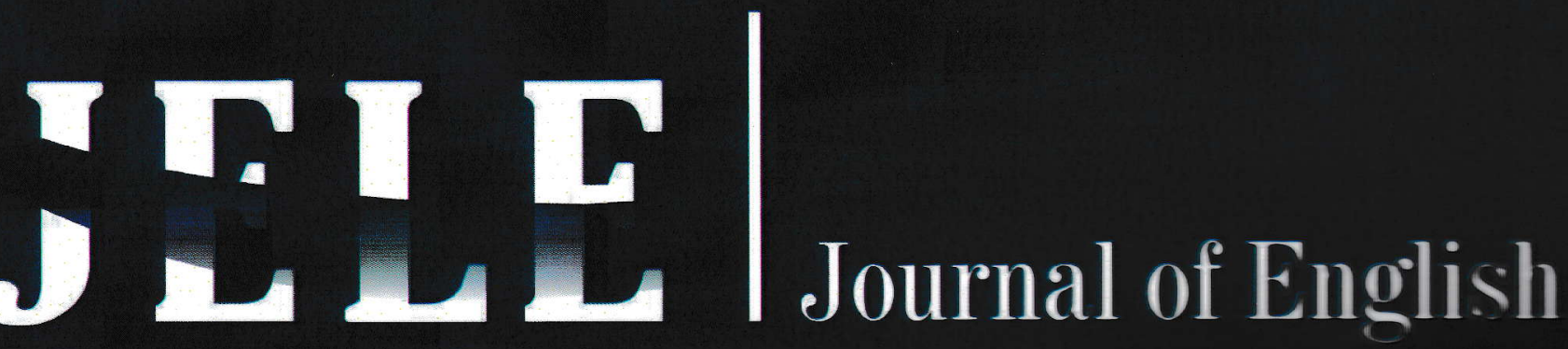 Language and Education
}

English Education Study Program Faculty of Teachers Training and Education Mercu Buana University of Yogyakarta 


\title{
Improving Students' Listening Competence by Using Contextual Teaching and Learning \\ (A Classroom Action Research Conducted at the Second Grade of MTs. Ma'arif 2 Muntilan, Magelang)
}

\author{
Happy Annisa' Octaviani ${ }^{1}$, Hermayawati ${ }^{2}$ \\ ${ }^{1,2}$ English Education Study Program, Faculty of Teachers Training and Education \\ Mercu Buana University of Yogyakarta \\ ${ }^{1}$ Email : rucortzrera@yahoo.co.id \\ ${ }^{2}$ Email : hermayawati@yahoo.com
}

\begin{abstract}
This research was conducted to improve students' listening competence by using Contextual Teaching and Learning (CTL) method. The aims of conducting this research were as follows: (1) improving students' listening competence through CTL; (2) finding the students' interest improvement on their listening by using CTL; (3) finding the improvement of the students' listening competence by using CTL. The Classroom Action Research was used by the researcher in conducting this research. Furthermore, the pre-test, treatments, and post-test were given to find the students' listening improvement in learning using CTL.The result of the research showed that CTL could improve the students' listening competence. It could be seen from the average scores in the pre-test and post-test. The average score of students in the pretest was about fifty six point two. Meanwhile, the average score in the first post-test and second post-test were seventy two point five and eighty point six. The result of the students' average score showed the improvement in their listening achievement by by using CTL. The students' interest improved through the students' active contribution during the learning processes which was measured by using scoring rubric of "metacognitive rubric motivation". Therefore, it can be concluded that CTL is effective to teach listening to the students. In short, the method can be used by the teacher as an alternative to teach listening.
\end{abstract}

Keywords: Classroom Action Research, CTL, Listening, Method, Motivation

\section{INTRODUCTION}

Language is the system of communication consisting of sounds, words, and grammar that it is used by people to communicate between each other. Moreover, it is as a communication tool to convey ideas, opinions, and even feelings to other members of society. As a communication tool, language is very important to human life. There are many languages that are used by people in the world, such as English, Spanish, Portuguese, Arabic, Indonesia, Mandarin, etc. One of the languages mostly used in the world is English. English has become an international language. As an international language, it has an 
important role in the world, especially in the globalization era like today.

In Indonesia, English is considered as the first foreign language. As the first foreign language, it should be taught in the school. Students have to learn it from elementary school until university. Based on the previous studies, although it has been learnt by the students since in elementary school, they have not mastered it yet. There are many factors which affect it such as the materials, teaching learning process in the class, teaching method, facilities, or even the student themselves who do not have high motivation to learn English (Milena: 2014). The condition above also happens to the students in MTs Ma'arif 2 Muntilan, Magelang. This school can be classified as good school because they get score A for the accreditation. The school also uses School-Based Curriculum (KTSP) for the second and the third grade students, while the first grade uses the new curriculum, Curriculum 2013. Based on the early observation and interview with the teacher and some students there, it was found that many students in MTs Ma'arif 2 Muntilan had problems in learning English. Although the students have studied English from elementary school, they still had difficulties in mastering English. In English there are four skills (listening, speaking, reading, and writing) that should be mastered, but the skill that they felt most difficult was listening. From the observation, there were three things that were very important to be noted such as materials, facilities, and their motivation. The first was about materials. Sometimes, the material that the teacher gave to the students just from the English book. Even though the teacher gave them the materials from other sources, but they still had difficulties to catch what they heard. It was because the materials that did not really related to the real life. If the students had difficulties in guessing what words they listened it would be easier if the materials related to the real life because they could guess the words. The second was about the facilities in the school. This school did not have language laboratory. Students rarely got listening practice. If they got listening practice, it was just in the class and used tape. The teacher also often used teacher's talk or teacher's 
reading aloud (manual listening) to teach listening. However, although it just used teacher's reading aloud, it was more effective to the students. From the observation, the researcher could conclude that they would absorb the materials well from the teacher's reading aloud than from the recorder because of the situation and condition around the class. Other students from other classes sometimes were noisy and disturbed students while they had listening practice in the class by using recorder. They considered that it would be clearer from the teacher's reading aloud. The last problem was about their motivation. Actually they liked English, but sometimes the teacher did not really care with their motivation. If they got difficulties, tired, bored, sleepy, afraid in making mistakes, the teacher just let them. They still needed more motivation from the teacher. When they got bored or sleepy, the teacher should try another way to make them wake up. Sometimes, if the teacher gave them instruction in English they did not understand what they had to do. Even in the simple instruction, the teacher should repeat it for two or three times. So, the teacher had to explain in
Indonesian. As Nunan (2005:13) states "it is important that the students are presented with language that they can understand" so that bilingualism is still needed for them in this school. Moreover, it became more difficult if the materials did not relate to their real life which made them more confused. They got difficulty to guess what the text was about. In fact, if the materials related to their real life, it would help them to imagine what they were studying or hearing. From the interview and observation explained above, the researcher believed that the difficulties in listening and motivation were the crucial problems there. Linse and Nunan (2005:25) states that listening is the foundation for other skills like speaking, reading, and writing. If the foundation is not strong enough, the other skills will be more difficult to master. As we know that the sequences of learning language start from listening, speaking, reading, and writing. If listening as the foundation is not mastered, the other skills will be more difficult also to master.

From the explanation above, the researcher interested to overcome the problems. But, the researcher 
focused on how to improve student's listening competence by using Contextual Teaching and Learning (CTL) at the second grade of MTs. Ma'arif 2 Muntilan, Magelang. Not only focusing on improving listening competence, but also the researcher will try to give more motivation to the students in learning listening using Contextual Teaching and Learning (CTL) method related to the real life, hopefully it could be the alternative strategies to improve students listening competence.

\section{The Nature of Listening}

\section{Competence}

Listening is one of the four skills in English beside speaking, reading, and writing. Here are some definitions of listening proposed by some writers: (a) According to Oxford Advanced Learner's Dictionary $5^{\text {th }}$ Edition, listen means "paying attention to somebody/something that you can hear"; (b) "Listening is a skill and any help we can give students in performing that skill help them to better listeners" (Harmer, 1998:98); (c) According to Scott (1990:21) Listening is the first skill that children acquire first, especially if they have not learnt to read; (d) "Listening as a major component in language learning and teaching first" (Brown, 2001:247).

From all the definitions above, it can be concluded that listening is the first step in learning a language and a complex process of interpretation in which listeners match what they hear with what they have already known before. As the researcher has been written before, listening is the first step in learning a language, so it is very important to teach listening well and make students understand.

In the teaching learning process, students need to have some competences in mastering the objectives of the study. Competence itself is being able to do something well (Oxford, 1995:232). There are some competences that students have to master. For example in listening competence, students have to answer based on the teacher questions orally, they can respond well to the teacher's instruction or even complete the text while listening.

On the other hand, listening competence is being able to listen well and they can respond well both in writing or orally. This skill is important because if students can't 
listen well, they can't respond to the teacher's instruction or question. "Listening to a foreign language is a hard work, especially for young children/learners"

(Brewster, 2002:98). Making students have good competences in listening is hard thing. According to Brewster (2002:98);

It is important to remember that listening is not a passive activity. Always asking students to simply "listen and remember" may make them feel anxious, places a great strain on their memory and tends not to develop listening skill. The teacher will be able to support children's understanding more effectively if the teacher directs her student's attention to specific points that have to be listened for. Using authentic materials that relate to the real life may help them so much in learning process.

Using Contextual Teaching and Learninghelps students in catching the sentences or words in understanding what they hear. CTL serves the materials that the students get in the classroom and relate it to the real world situation. Besides, it may be easier for them in learning listening because of the relation of materials and the students' real life.

\section{Motivation}

According to Woolfolk (2007:372) motivation is usually defined as "an internal state that arouses, direct, and maintains behavior". Motivation is divided into two major points. The first is Intrinsic Motivation and the second is Extrinsic Motivation. "Intrinsic Motivation is the natural tendency to seek out and conquer challenges as we pursue personal interest and exercise capability" (Deci \& Ryan, et al) cited in (Woolfolk: 2007). While "extrinsic Motivation is something that we do in order to earn a grade, avoid punishment, please the teacher, or for some other reason that has very little to do with the task" (Woolfolk:2007). Both intrinsic and extrinsic motivation affect the students in learning language. Teacher's skill in motivating learners plays an important role in student's achievement, especially for the students that have lack of motivation to learn English. As Dornyei (2001:116) notes "teacher 
skills in motivating learners should be seen as central to teaching effectiveness". Lack of motivation leads to lack of focus and effort, and ultimately lack of success. Teacher must figure out effective techniques to motivate students, so that, students make improvements in their English language capabilities. As Dornyei (2001) states that giving motivation can be done such as by giving appropriate teacher behavior, creating a pleasant and supportive atmosphere in the classroom (basic motivational conditions). Encourage the students by saying "do not be afraid in making mistakes" is also the best way to make them more motivated. Besides, teachers also can give appraisal and reward to the students. Table 1 shows some activities in the classroom that the researcher did to motivate students by Dornyei. 
Table 1. The list of the action in the classroom (Dornyei, 2001: 31- 49)

\begin{tabular}{|c|c|c|}
\hline Creating The Basic Motivational Conditions & $\begin{array}{l}\text { Tried } \\
\text { it out }\end{array}$ & $\begin{array}{l}\text { Part of } \\
\text { my } \\
\text { teaching }\end{array}$ \\
\hline \multicolumn{3}{|l|}{$\begin{array}{l}\text { 1. Demonstrate and talk about resercher's own antushiasm for the } \\
\text { course materials, and how it effects resercher personally. }\end{array}$} \\
\hline $\begin{array}{l}\text { Share researcher's personal interest in the L2 with the students. } \\
\text { Show students that researcher value L2 learning as a meaningful experience } \\
\text { that produces satisfication and enriches researcher's life. }\end{array}$ & $\begin{array}{l}\sqrt{ } \\
\sqrt{ }\end{array}$ & \\
\hline \multicolumn{3}{|l|}{ 2. Take the students' learning very seriously } \\
\hline $\begin{array}{l}\text { Show students that researcher care about their progress. } \\
\text { Indicate resercher mental and physical availability for all things academic. } \\
\text { Have sufficiently high expectations for what researcher's students can achive. }\end{array}$ & $\sqrt{ }$ & \\
\hline \multicolumn{3}{|l|}{ 3. Develop a personal relationship with the students } \\
\hline $\begin{array}{l}\text { Show students that resercher accept and care about students. } \\
\text { Pay attention and listen to each of them. } \\
\text { Indicate researcher's physical and mental availability. }\end{array}$ & $\sqrt{ }$ & \\
\hline \multicolumn{3}{|l|}{ 4. Develop a collaborative relationship with the student's parent. } \\
\hline \multicolumn{3}{|l|}{$\begin{array}{l}\text { Keep parent regularly informed about their children's progress } \\
\text { Ask for their assistance in performing certain supportive tasks at home. }\end{array}$} \\
\hline \multicolumn{3}{|l|}{ 5. Create a plesant and supportive atmosphere in the classroom. } \\
\hline $\begin{array}{l}\text { Established a norm tolerance. } \\
\text { Encourage risk-taking and have mistakes accepted as a natural part of } \\
\text { learning. } \\
\text { Bring in and encourage humor. } \\
\text { Encourage learners to personalise the classroom environment according to } \\
\text { their taste. }\end{array}$ & $\sqrt{ }$ & \\
\hline \multicolumn{3}{|l|}{ 6. Promote the development of group cohessiveness. } \\
\hline \multicolumn{3}{|l|}{$\begin{array}{l}\text { Try and promote interaction, coooperation and the sharing of genuine } \\
\text { personal information among learners. } \\
\text { Use Ice-breakers at the begining of a course. } \\
\text { Regularly use small-group task where students can mix. } \\
\text { Encourage and if possible organise extracurricular activities and outing. } \\
\text { Try and prevent the emergence of rigid seating patterns. } \\
\text { Include activities that lead to the successful completion of whole group tasks } \\
\text { or involve small-group conpetition games. } \\
\text { Promote the building of a group legend. }\end{array}$} \\
\hline \multicolumn{3}{|l|}{$\begin{array}{l}\text { 7. Formulate group norms explicitly, and have them discussed and } \\
\text { accepted by the learners. }\end{array}$} \\
\hline $\begin{array}{l}\text { Include a spesific group rules activities at the beginning of a group's life to } \\
\text { establish the norm explicily. } \\
\text { Explain the importance of the norms researcher mandate and how they } \\
\text { enhance learning, and ask for the students agreement. } \\
\text { Elicite suggetion for aditional rules from the learners and discuss these in the } \\
\text { same way as the rules that has proposed. }\end{array}$ & & \\
\hline
\end{tabular}


All the ticks above were done by the researcher to improve students' motivation. To find out the improvement of students' motivation, the researcher used the following rubric. Table 2 explains about the stage of motivation. The lowest stage of metacognitive motivation is in column 1, and the highest stage is in column 5 .

Table 2. Metacognitive rubric motivation

\begin{tabular}{|c|c|c|c|c|}
\hline 1 & 2 & 3 & 4 & 5 \\
\hline $\begin{array}{l}\text { Strong external } \\
\text { locus of control, } \\
\text { Blames others } \\
\text { for lack of } \\
\text { success; }\end{array}$ & $\begin{array}{l}\text { External } \\
\text { locus of } \\
\text { control, } \\
\text { Often blames } \\
\text { others for } \\
\text { lack of } \\
\text { success; }\end{array}$ & $\begin{array}{l}\text { Sometimes } \\
\text { accepts } \\
\text { responsibility, } \\
\text { Sometimes } \\
\text { blames others for } \\
\text { lack of success; }\end{array}$ & $\begin{array}{l}\text { Has internal } \\
\text { locus of } \\
\text { control, takes } \\
\text { responsibility } \\
\text { for success and } \\
\text { failures }\end{array}$ & $\begin{array}{l}\text { Has strong internal } \\
\text { locus of control, } \\
\text { takes full } \\
\text { responsibility for } \\
\text { success and failures; }\end{array}$ \\
\hline Has no goals & $\begin{array}{l}\text { Has } \\
\text { unrealistic } \\
\text { goals and no } \\
\text { plans to } \\
\text { achieve them }\end{array}$ & $\begin{array}{l}\text { Has unrealistic } \\
\text { goals or vague } \\
\text { plans to achieve } \\
\text { goals }\end{array}$ & $\begin{array}{l}\text { Sets realistic } \\
\text { goals and } \\
\text { makes plans to } \\
\text { achieve them }\end{array}$ & $\begin{array}{l}\text { Sets realistic goals } \\
\text { and makes } \\
\text { concrete, written } \\
\text { plans to achieve } \\
\text { them }\end{array}$ \\
\hline $\begin{array}{l}\text { Always needs } \\
\text { direction. Does } \\
\text { not complete } \\
\text { distasteful tasks } \\
\text { or tasks for } \\
\text { which there is } \\
\text { no drive }\end{array}$ & $\begin{array}{l}\text { Usually } \\
\text { needs } \\
\text { direction. } \\
\text { Seldom } \\
\text { completes } \\
\text { distasteful } \\
\text { tasks or tasks } \\
\text { for which } \\
\text { there is no } \\
\text { drive }\end{array}$ & $\begin{array}{l}\text { Often needs } \\
\text { direction. } \\
\text { Sometimes } \\
\text { completes } \\
\text { distasteful tasks } \\
\text { or tasks for which } \\
\text { there is no drive }\end{array}$ & $\begin{array}{l}\text { Is self directed } \\
\text { or regulated } \\
\text { and usually } \\
\text { completes } \\
\text { distasteful } \\
\text { tasks or tasks } \\
\text { for which the } \\
\text { drive is not } \\
\text { present }\end{array}$ & $\begin{array}{l}\text { Is very self directed } \\
\text { or regulated and } \\
\text { completes } \\
\text { distasteful tasks or } \\
\text { tasks for which the } \\
\text { drive is not present }\end{array}$ \\
\hline $\begin{array}{l}\text { Has no sense of } \\
\text { time } \\
\text { management }\end{array}$ & $\begin{array}{l}\text { Has a vague } \\
\text { idea of how } \\
\text { to manage } \\
\text { time }\end{array}$ & $\begin{array}{l}\text { Understands the } \\
\text { importance of } \\
\text { time management } \\
\text { but has no system } \\
\text { or does not } \\
\text { implement a plan }\end{array}$ & $\begin{array}{l}\text { Has an } \\
\text { effective time } \\
\text { management } \\
\text { system and } \\
\text { uses it most of } \\
\text { the time. }\end{array}$ & $\begin{array}{l}\text { Has a well } \\
\text { developed, } \\
\text { effective time } \\
\text { management } \\
\text { system and uses it } \\
\text { regularly }\end{array}$ \\
\hline $\begin{array}{l}\text { Does not care } \\
\text { about success. } \\
\text { Has a negative } \\
\text { attitude. Very } \\
\text { stressed. }\end{array}$ & $\begin{array}{l}\text { Sometimes } \\
\text { tries to do } \\
\text { well, but has } \\
\text { a negative } \\
\text { attitude. Is } \\
\text { experiencing } \\
\text { stress. }\end{array}$ & $\begin{array}{l}\text { Tries to do well } \\
\text { but has trouble } \\
\text { keeping a positive } \\
\text { attitude. Has } \\
\text { trouble with } \\
\text { stress. }\end{array}$ & $\begin{array}{l}\text { Usually strives } \\
\text { to do well and } \\
\text { retains a } \\
\text { positive } \\
\text { attitude. } \\
\text { Manages } \\
\text { stress. }\end{array}$ & $\begin{array}{l}\text { Always strives to } \\
\text { do well; controls } \\
\text { attitude with } \\
\text { positive self talk; } \\
\text { manages stress } \\
\text { effectively }\end{array}$ \\
\hline
\end{tabular}




\section{Contextual Teaching and Learning}

Berns and Erickson (2001) define that:

Contextual Teaching and Learning (CTL) as method of teaching and learning which helps teachers relate subject matter or content to the real world situations, and motivates students to make connections between knowledge and its application to their lives.In contextual learning theory, learning occurs only when students process new information or knowledge in such a way that it makes sense to them.

Another definition promoted by Johnson (2002:25) is that "CTL is an educational process that help student see meaning in the academic subject with the context of their daily lives, that is, with the context of their personal, social, and cultural circumstances". To achieve this aim, it covers the following eight components: "(1) making meaningful connections; (2) doing significant work; (3) self-regulated learning; (4) collaborating; (5) critical and creative thinking; (6) nurturing the individual; (7) reaching high standards, and (8) using authentic assessments" (Johnson, 2002:65-66). In other word, when talking about context, most people say that it is related to their social life. In the classroom teaching, CTL means teacher should present the student real world inside the classroom.

There are some strategies in CTL. They are problem based, using multiple context, drawing upon students diversity, supporting selfregulated learning, using interdependent learning groups, employing authentic assessment (Johnson, 2002:21-23). CTL emphasizes the student's involvement in the whole process to be able to seek out the material learned and relate the real life situation in order to motivate students to apply the knowledge or skill acquired in their life. Besides, it helps the teacher relate the subject matter content to real world situation and motivate students to make connections between knowledge and its applications to their lives as family members, citizens, and workers in the hard work that learning requires. Moreover, one of the teacher's roles in CTL is to motivate students to learn. The motivation can be in the form of appraisal or reward. Teachers also create or facilitate students by 
designing "a supporting learning atmosphere" in the classroom.

From the explanation above, it can be concluded that CTL relates to the real life and teachers try to present it to the class. Through relating it, it can be more beneficial for the students and not only learning in the class but also, they can more understand how to implement it. On the other hand, the teacher's role is as facilitator or even motivator to motivate students in learning the materials in the class.

\section{METHODS}

This research belongs to a collaborative Classroom Action Research. The research involved collaboration and cooperation between the researcher and the English teacher. Both the English teacher and the researcher worked as a team teaching in the implementation. Furthermore, Hopkins (2008:47) defined that "action research combines a substantive act with a research procedure; it is action disciplined by enquiry, a personal attempt at understanding while engaged in a process of improvement and reform. To carry out the action research, the research consisted of several cycles". The cycles depended on the situation which happened in the research setting. The cycle would not stop until there was improvement from the students in their listening competence. Based on Kemmis and Mc Taggart, there are four steps in action research. They are planning, acting, observing, and reflecting.

\section{FINDINGS AND DISCUSSIONS}

Dealing with the problem that happened to the students in MTs Ma'arif 2 Muntilan, the researcher conducted a research which consisted of two cycles. Each cycle had four stages, namely planning, acting, observing, and reflecting. The lesson plan, the observation sheet, materials and method had been prepared and designed by the researcher. All the plans ran well but sometimes, there was unexpected condition or result in the implementation of the cycle that needed to be improved.

The students' interest also became the important aspect in the teaching and learning process. Without interest in learning, the learning achievement will not be 
satisfying. Lack of motivation leads to lack of focus and effort, and ultimately lack of success". From the need analysis, designing the plans of research, cyclical implementations, reflection, etc the students' interest in learning English could be seen. They were more active in joining the teaching and learning processes in the class. Researcher implemented the materials which might draw the students' interest. Based on the interview that was conducted after the two cycles with the same students, it was found that the students felt enjoyable in learning listening using Contextual Teaching and Learning. They could relate the materials with their real life and made the teaching learning process more enjoyable. Even, when they did not know the words or sentences that they were hearing, they could guess because it had relation to their real life. Besides, the researcher's reading aloud also helped them in catching what words or sentences they were hearing. Good, clear, and right pronunciation had important role to improve their achievement in listening competence.

The students could improve their motivation because the researcher applied the basic motivational strategies by Dornyei (2001). Researcher implemented some actions such as the researcher showed the interest of the L2 to the students, cared to the students both their attitude or achievement in their score, established norm tolerance, gave ice breaker before the teaching learning process and regularly used group works in the teaching learning process or did the assignment. After implementing those strategies, the researcher could see the improvement of students' motivation. The scoring rubric motivation showed that before the treatments the students sometimes blamed the other mistakes, having lack of responsibility in learning or even did the assignment. Even, they had to be instructed to do the task. But after the treatments, the students were respect their other friends, the responsibility was also improved. If researcher gave them task, they were enthusiastics to do it. Even, they became more responsible and enjoyed in the class. The attitude was better than before. It could be seen like in the table metacognitive rubric motivation. From the beginning, the students were in the column number 1 , but after 
treatments, they were in the column number 3. There were no specific scores to know the improvement of the students' motivation, but it is from the researcher' observation during the research. The researcher had notes about every students, so during the research, the researcher knew the improvement of the students' motivation.

\begin{tabular}{|c|c|c|c|c|}
\hline 1 & 2 & 3 & 4 & 5 \\
\hline $\begin{array}{l}\text { Strong } \\
\text { external } \\
\text { locus of } \\
\text { control, } \\
\text { Blames } \\
\text { others for } \\
\text { lack of } \\
\text { success; }\end{array}$ & $\begin{array}{l}\text { External locus } \\
\text { of control, } \\
\text { Often blames } \\
\text { others for lack } \\
\text { of success; }\end{array}$ & $\begin{array}{l}\text { Sometimes accepts } \\
\text { responsibility, } \\
\text { Sometimes blames } \\
\text { others for lack of } \\
\text { success; }\end{array}$ & $\begin{array}{l}\text { Has internal locus } \\
\text { of control, takes } \\
\text { responsibility for } \\
\text { success and } \\
\text { failures }\end{array}$ & $\begin{array}{l}\text { Has strong internal } \\
\text { locus of control, takes } \\
\text { full responsibility for } \\
\text { success and failures; }\end{array}$ \\
\hline Has no goals & $\begin{array}{l}\text { Has } \\
\text { unrealistic } \\
\text { goals and no } \\
\text { plans to } \\
\text { achieve them }\end{array}$ & $\begin{array}{l}\text { Has unrealistic } \\
\text { goals or vague plans } \\
\text { to achieve goals }\end{array}$ & $\begin{array}{l}\text { Sets realistic } \\
\text { goals and makes } \\
\text { plans to achieve } \\
\text { them }\end{array}$ & $\begin{array}{l}\text { Sets realistic goals and } \\
\text { makes concrete, } \\
\text { written plans to } \\
\text { achieve them }\end{array}$ \\
\hline $\begin{array}{l}\text { Always } \\
\text { needs } \\
\text { direction. } \\
\text { Does not } \\
\text { complete } \\
\text { distasteful } \\
\text { tasks or tasks } \\
\text { for which } \\
\text { there is no } \\
\text { drive }\end{array}$ & $\begin{array}{l}\text { Usually needs } \\
\text { direction. } \\
\text { Seldom } \\
\text { completes } \\
\text { distasteful } \\
\text { tasks or tasks } \\
\text { for which } \\
\text { there is no } \\
\text { drive }\end{array}$ & $\begin{array}{l}\text { Often needs } \\
\text { direction. } \\
\text { Sometimes } \\
\text { completes } \\
\text { distasteful tasks or } \\
\text { tasks for which } \\
\text { there is no drive }\end{array}$ & $\begin{array}{l}\text { Is self directed or } \\
\text { regulated and } \\
\text { usually completes } \\
\text { distasteful tasks } \\
\text { or tasks for which } \\
\text { the drive is not } \\
\text { present }\end{array}$ & $\begin{array}{l}\text { Is very self directed or } \\
\text { regulated and } \\
\text { completes distasteful } \\
\text { tasks or tasks for } \\
\text { which the drive is not } \\
\text { present }\end{array}$ \\
\hline $\begin{array}{l}\text { Has no sense } \\
\text { of time } \\
\text { management }\end{array}$ & $\begin{array}{l}\text { Has a vague } \\
\text { idea of how to } \\
\text { manage time }\end{array}$ & $\begin{array}{l}\text { Understands the } \\
\text { importance of time } \\
\text { management but has } \\
\text { no system or does } \\
\text { not implement a } \\
\text { plan }\end{array}$ & $\begin{array}{l}\text { Has an effective } \\
\text { time management } \\
\text { system and uses it } \\
\text { most of the time. }\end{array}$ & $\begin{array}{l}\text { Has a well developed, } \\
\text { effective time } \\
\text { management system } \\
\text { and uses it regularly }\end{array}$ \\
\hline $\begin{array}{l}\text { Does not } \\
\text { care about } \\
\text { success. Has } \\
\text { a negative } \\
\text { attitude. } \\
\text { Very } \\
\text { stressed. }\end{array}$ & $\begin{array}{l}\text { Sometimes } \\
\text { tries to do } \\
\text { well, but has a } \\
\text { negative } \\
\text { attitude. Is } \\
\text { experiencing } \\
\text { stress. }\end{array}$ & $\begin{array}{l}\text { Tries to do well but } \\
\text { has trouble keeping } \\
\text { a positive attitude. } \\
\text { Has trouble with } \\
\text { stress. }\end{array}$ & $\begin{array}{l}\text { Usually strives to } \\
\text { do well and } \\
\text { retains a positive } \\
\text { attitude. Manages } \\
\text { stress. }\end{array}$ & $\begin{array}{l}\text { Always strives to do } \\
\text { well; controls attitude } \\
\text { with positive self talk; } \\
\text { manages stress } \\
\text { effectively }\end{array}$ \\
\hline
\end{tabular}


At the beginning of the research, students were less motivated so that the researcher had to give clear explanation about the materials which were learning in the class. The cyclical processes implemented and the treatment was given to them to solve the problems. The two cycles were given to the students and the improvement could be seen. Both the average score of the students and the student's motivation were improved. These were the results of the pre-test, first post-test, second post-test:

1) The result of the students' average score in pre-test was:

$$
\mathrm{M}=\frac{\sum X}{N}=\frac{1460}{26}=56,2
$$

2) The result of the student's average score in the first post-test was:

$\mathrm{M}=\frac{\sum X}{N}=\frac{1885}{26}=72,5$

3) The result of the student's average score in the first post-test was

$\mathrm{M}=\frac{\sum X}{N}=\frac{2095}{26}=80,6$

From the result of the tests, it was found that there were different scores between pre-test, the first posttest, and the second post-test. The average score in pre-test was 56,2 . It was under the passing grade which was 75. It needed improvement. The students could not do the pre-test well.
Furthermore they were lack of motivation to do the pre-test well.

After implementing the treatments in the cycle one, the average score of the students improved. They got 72.5 for the first post-test. They could get the better average score because of the treatment by the researcher who used CTL method and gave more motivation to them.

Finally, in the second post-test the average score of the students improved and could reach higher than the passing grade. The average score in the second post-test was 80,6. It showed that the treatment could improve the students' listening competence.

From the explanation above, it can be concluded that CTL can be the alternative method to teach listening. The method is effective because it can improve the average score of the students. Furthermore, the method relates the materials to the students' real life. Meanwhile, motivation is also needed to improve the students' achievement especially listening competence at the class $8 \mathrm{~A}$ of MTs. Ma'arif 2 Muntilan. The method of Contextual Teaching and Learning and 
give more motivation could improve the student's listening competence. It could be seen in the result of pre-test, the first post-test, and the second posttest. In the pre-test the average score was 56,2 , the first post-test 72,5 , and the second post-test 80,6. Meanwhile, the improvement of the students' motivation could be seen in the metacognitive rubric motivation. At the beginning of the research, the students were in the column 1 , but after treatment, they were in the column 3. Furthermore, observation is used to score improvement of the students' motivation.

\section{CONCLUSION}

Based on the result of the data calculation above, it can be concluded as follows. The first was students' learning listening can be improved using CTL. It is known from the students' listening achievement in the pre-test, the first post-test, and the second post-test. On the other hand, the activities in the teaching and learning processes in the class were more enjoyable.

The second was the students' were much more motivated in learning than before. The encouragement from the researcher could improve their motivation. They can relate the materials that they get in the classroom with their daily life, so that they can be easily in joining the teaching learning process in the class. It also could be seen from "metacognitive rubric motivation".

The students' learning achievement were improved from 56.2 until 80.6. The result of the students' average score showed that CTL and gave more motivation could improve that students' listening achievement.

It can be concluded that CTL can be used as an alternative method to teach listening to the students. It does not only improve the students' listening score, but also motivate them to learn English seriously.

\section{REFERENCES}

Berns, R.G. and Erickson, P.M., (2001). Contextual Teaching and Learning:Preparing Students for the New Economy.

Brewster, J, Ellis, G \& Girard D. (2002).The Primary English 
Teacher's Guide. England

:Pearson Education Limited.

Brown,h.,d.(2001). Teaching by

Principles: an Interactive Approach Language

Pedagogy (second edition).

White Plains, New York:

Longman/Pearson Education.

Caroline T. Linse ; David Nunan.

(2005) Practical English

Language Teaching: young

learners. New York :

McGraw-Hill/Contemporary.

Dornyei, Z. (2001). Motivational Strategies in the Language

Classroom. Cambridge:

Cambridge University

Press.

Harmer, Jeremy. (1998). How to teach

English.

England:Longman.Pearson.

Education.

(2001). The

Practice of English Language

Teaching. $3^{\text {rd }}$ ed. London:
Wesley Company. Longman handbook.

Teach English. London: Longman.

Hopkins, David. (2008). A teacher's Guide to Classroom Research. New York: Open University Press.

Johnson, Elaine B. (2002). Contextual Teaching and Learning: What It is and Why It's Here to Stay. USA: Corwin Press.

Kemmis, Stephen, and Mc. Taggart, Robbin. (1988). The Action Research Planner. $3^{\text {rd }}$ ed. Victoria: deakin University Press.

Oxford. (1995). Oxford: Advanced Learner's Dictionary. $5^{\text {th }}$ ed. English: Oxford University Press.

Scott. A. Wendy and Yteberg Lisbeth. (1990). Teaching English to Children. New York:Longman. Inc. 


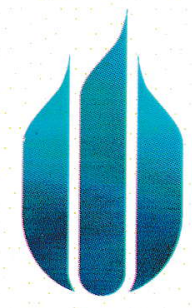

U N I VER S I TAS

MERCU BUANA

Y O G Y A K A R T A

ENGLISH EDUCATION STUDY PROGRAM

Faculty of Teachers Training and Education

Mercu Buana University of Yogyakarta

J. Wates Km. 10 Yogyakarta 55753 | jurnal.umby@gmail.com

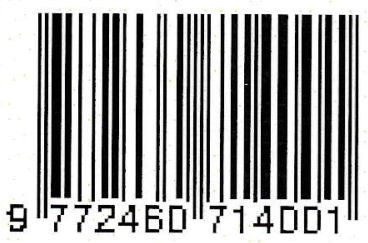

